\title{
Histomorphometric analysis of bone tissue repair in rabbits after insertion of titanium screws under different torque ${ }^{1}$
}

\author{
Estudo histomorfométrico do reparo tecidual ósseo de coelhos com parafusos de titânio \\ inseridos sob diferentes intensidades de torques
}

\author{
Fabrício Togni', Fabíola Baras", Marina de Oliveira Ribas ${ }^{\mathrm{III}}$, Murched Omar Taha ${ }^{\mathrm{IV}}$ \\ ${ }^{1}$ Research performed at Operative Technique and Experimental Surgery Division, Surgery Department, Federal University of Sao Paulo (UNIFESP), \\ Brazil. Part of Master degree thesis.

\begin{abstract}
${ }^{\mathrm{I}}$ Fellow Master degree, Operative Technique and Experimental Surgery Division, Surgery Department, UNIFESP, Sao Paulo, Brazil. Concepcion, design and scientific content of the study. Surgical procedures. Analysis and interpretation of data. Manuscript writing. Critical revision.

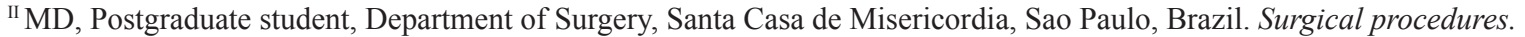

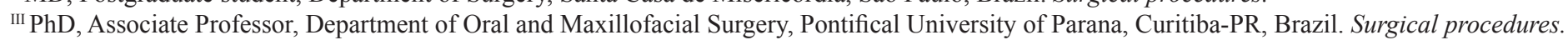

${ }^{I V} \mathrm{PhD}$, Affiliate Professor, Operative Technique and Experimental Surgery Division, Surgery Department, UNIFESP, Sao Paulo, Brazil. Manuscript writing and critical revision.
\end{abstract}

\begin{abstract}
Purpose: To evaluate the inflammatory response of rabbit bone after insertion of titanium screws under different torque values. Methods: Four holes were made in the back tibia of fifteen New Zealand male albino rabbits; three screws were placed in each animal and a control hole remained without a screw. The screws were inserted with 0,5 or $10 \mathrm{~N} . \mathrm{cm}$ of torque. The animals were assigned to five groups according to the day of sacrifice after surgery $(2,7,14,21$ or 42 days). The inflammatory cells and the thickness of the bone tissue around the screws was count. Results: The screws were associated with a larger number of inflammatory cells when compared to the control hole. There was no statistically significant difference when several comparisons were made among the groups with different torque intensity. Conclusions: The histological changes were not statistically significant. There was a trend toward an increase in inflammatory cells found in local bone tissue surrounding the titanium screws installed with the highest torque. There was a tendency toward the formation of a lower thickness of tissue surrounding those bone screws that were inserted with higher torque.
\end{abstract}

Key words: Torque. Bone Screws. Bone Remodeling. Rabbits.

\section{RESUMO}

Objetivo: Avaliar em variados períodos de tempo a resposta inflamatória do tecido ósseo de coelhos nos quais foram instalados parafusos de titânio com variadas intensidades de torque. Métodos: 15 coelhos Nova Zelândia receberam três parafusos de titânio instalados em cada tíbia traseira e uma perfuração sem parafuso. Foram inseridos os parafusos com 0,5 e 10 N.cm de torque. A eutanásia ocorreu 2,7 , 14, 21 e 42 dias pós-operatórios e foram analisados a em microscopia óptica a quantidade de células inflamatórias e espessura do tecido ósseo formado. Resultados: Observou-se que a presença de parafusos apresentou uma quantidade significantemente maior de células inflamatórias quando comparado às perfurações controle. Houve um aumento na formação de tecido ósseo adjacente aos parafusos dos grupos 14, 21 e 42 dias quando comparados aos demais. Conclusões: Quanto maiores foram os torques de instalação dos parafusos de titânio, maiores foram as quantidades de células inflamatórias locais observadas nos tecidos ósseos circundantes e que com o passar dos períodos de tempo, foram diminuindo gradativamente. As espessuras de tecidos ósseos formadas observadas ao redor dos parafusos inseridos foram proporcionalmente menores quando a intensidade dos torques aplicados foram cada vez maiores.

Descritores: Torque. Parafusos Ósseos. Remodelação Óssea. Coelhos. 


\section{Introduction}

Bone immobilization with rigid internal fixation - RIF (plates and screws) instead of steel wires has been one of the most important changes in oral and maxillofacial surgery. Owing to the evolution of surgical techniques, the development of new screws and plates and the discovery of biocompatible materials, RIF is now considered essential for surgical success ${ }^{1,2}$.

Several mechanical factors interfere with treatment outcome. One of these is the screw insertion torque value used on the tissue. Torque is directly related to bone stability, and excessive torque may cause micro-fractures ${ }^{3}$. Insertion torque values were analyzed using fresh bone. A maximum torque value (without producing micro fractures) of 70 N.cm could be used on bicortical bone and $50 \mathrm{~N} . \mathrm{cm}$ on monocortical bone ${ }^{4}$. Currently, there are no standard insertion torque values in bone tissue, and it is not well established whether measuring these values is really necessary. None of the RIF kits have a screwdriver with a torquimeter. Torque is clinically important, and that the surgeon should use his or her experience to quantify the force ${ }^{5}$. Excessive manual force was found to be responsible for too much tension on the bone, which caused an absorbent response, which means that screw insertion with higher torque values may create harmful forces on the implant. However the ideal torque value for screw insertion remains unknown ${ }^{6}$. The objective of this study was to histomorphometrically evaluate bone tissue repair in rabbits after different periods following titanium screw insertion under different torque values.

\section{Methods}

This research was approved by the Ethical Committee on Research of the Federal University of Sao Paulo. Fifteen male albino rabbits Oryctolagus Cuniculus, five months old that weighed around $3200 \mathrm{~g}$ were selected. The anesthetic solution was made with Xylazina $0.1 \mathrm{ml} / \mathrm{kg}$ (Rompun-Bayer ${ }^{\square}$, Sao Paulo, Brazil) and Ketamina 50 mg/kg (Vetanarcol - König $\square$, Sao Paulo, Brazil) and was injected intramuscularly. The procedure started with a $5 \mathrm{~cm}$ cut from the anterior knee region to the caudal region. Four holes were made in the back tibia with an electric drill (Driller ${ }^{\square}$, Sao Paulo, Brazil) with a constant speed of 1400 rotations per minute, under irrigation with saline solution. The screws used in this study were 90 self-tapping titanium screws, with an external diameter of $2.0 \mathrm{~mm}$ and a length of $7 \mathrm{~mm}$ (Neoface ${ }^{\circledR}$, Curitiba, Brazil). Of these four holes in each tibia, three received screws and one served as a control for histological comparison. The screws were randomly allocated and inserted with the standard screwdriver (Figure 1).

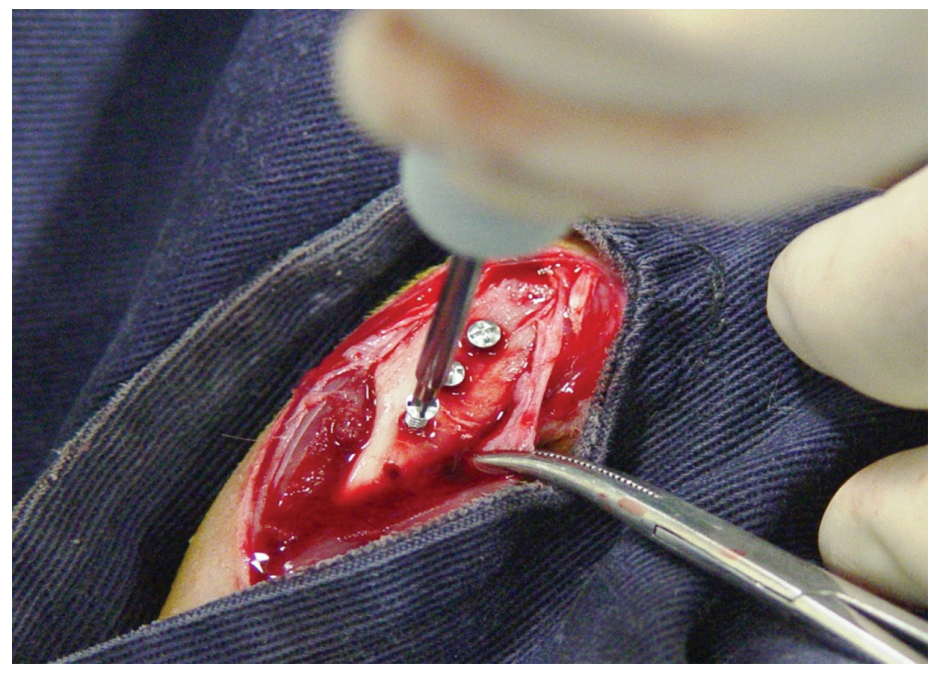

FIGURE 1 - Screw insertion in rabbit bone tissue.

A torquimeter was developed (Neodent ${ }^{\circledR}$ Curitiba, Brazil) in order to quantify the torque applied. The values were established with a pilot test which also used titanium screws and a fresh rabbit tibia $^{7}$. A digital torquimeter (Instrutherm ${ }^{\circledR}$ TQ-680, Sao Paulo, Brazil) was used to place the screws until they spun around and scraped off the bone tissue. The torque value was quantified between 12 N.cm and 15 N.cm. In order to avoid exceeding these limits, the maximum insertion torque value was standardized at $10 \mathrm{~N} . \mathrm{cm}$ in this study. For a better evaluation of torque effects on bone tissue, the values of 0 N.cm (no torque) and 5 N.cm were also studied. Each tibia was drilled four times, and a screw was placed in three of these holes under a torque intensity of 10 N.cm, 5 N.cm and 0 N.cm (Figure 2).

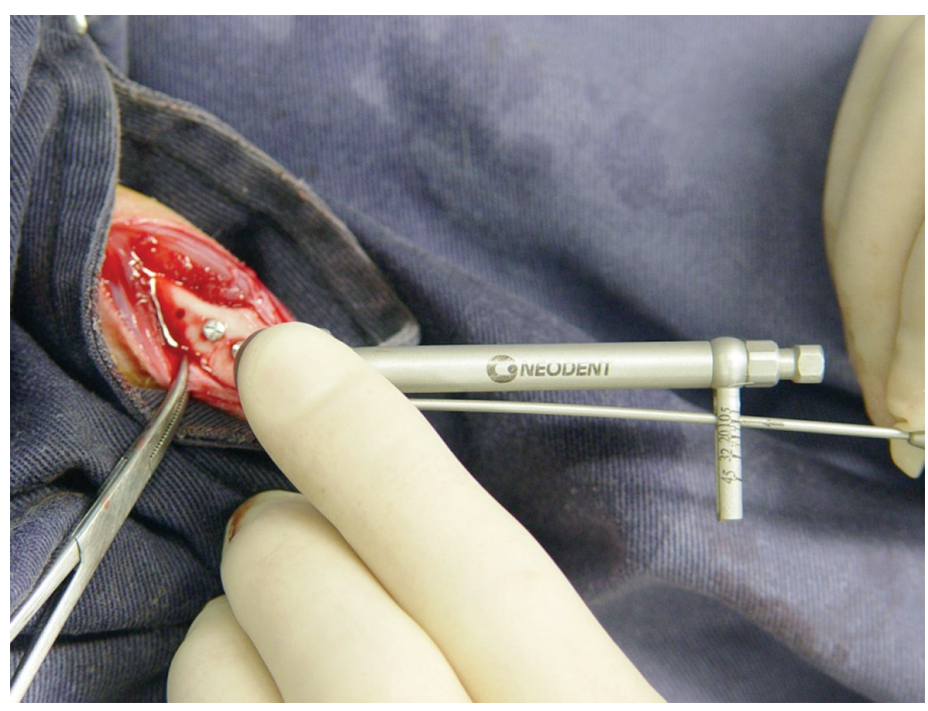

FIGURE 2 - Application of the insertion torque values on the screws. 
Nylon 4.0 (Ethicon, Los Angeles, USA) was used for wound closure. Administered drugs for pain control and antibiotics for five days after surgery to all animals. The animals were divided into five groups according to the day of sacrifice after surgery (A:2; B:7; C:14; D:21; and E:42 days). The bones were put in a $10 \%$ formalin solution for 15 days and then they were decalcified in $10 \%$ formic acid for 60 days. The screws were removed and the bones were embedded in blocks of paraffin, cut along the long axis of the screw and stained with hematoxylin and eosin (HE) for histological analysis. Laminas were analyzed with a light microscope (magnification of 20x and 40x) VS1Z Video Inspection System $^{\circledR}$ (Lab Essentials Inc, Monroe, USA) with the Image Pro Plus ${ }^{\circledR}$ program (Media Cybernetics, Bethesda, USA) to quantify the inflammatory cells (ICN) at the bone repair site and to measure the bone tissue thickness (BTT) around the screws. ICN was obtained by counting all polymorphonuclear cells from six quadrangular sections measuring $200 \times 200$ micrometers (three on each side around the place the screw), respectively located in the first, third, and fifth spires formed in the bone bed observed ${ }^{8}$. The BBT was measured by six linear measures perpendicular to the first, third and fifth spires bone observed on each side of the sites of the screws removed (Figures 3 and 4).

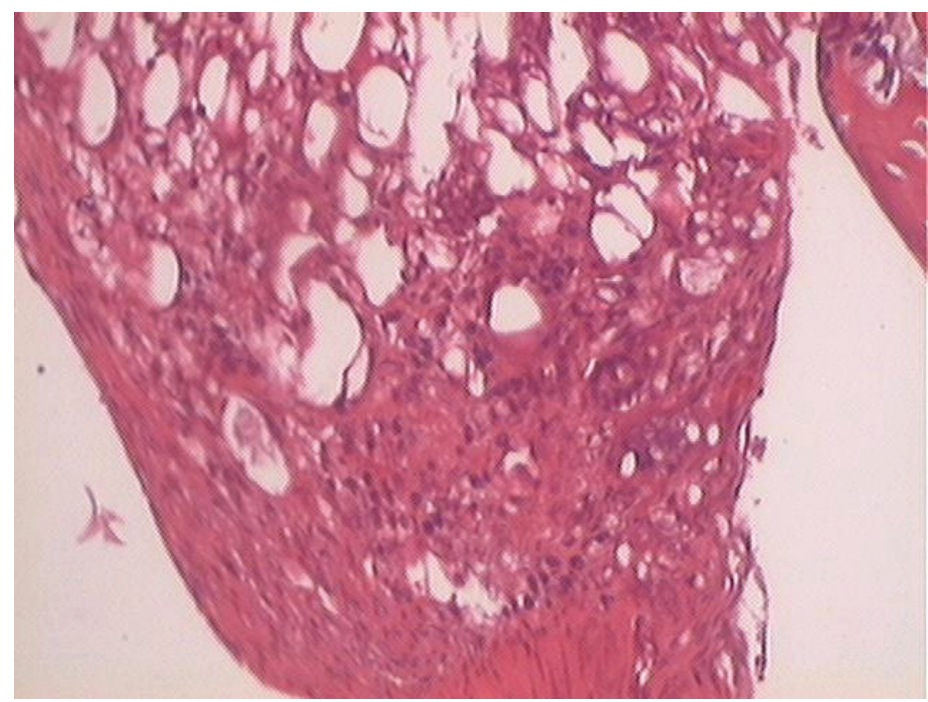

FIGURE 3 - Photomicrography showing inflammatory cell migration to the screw site.

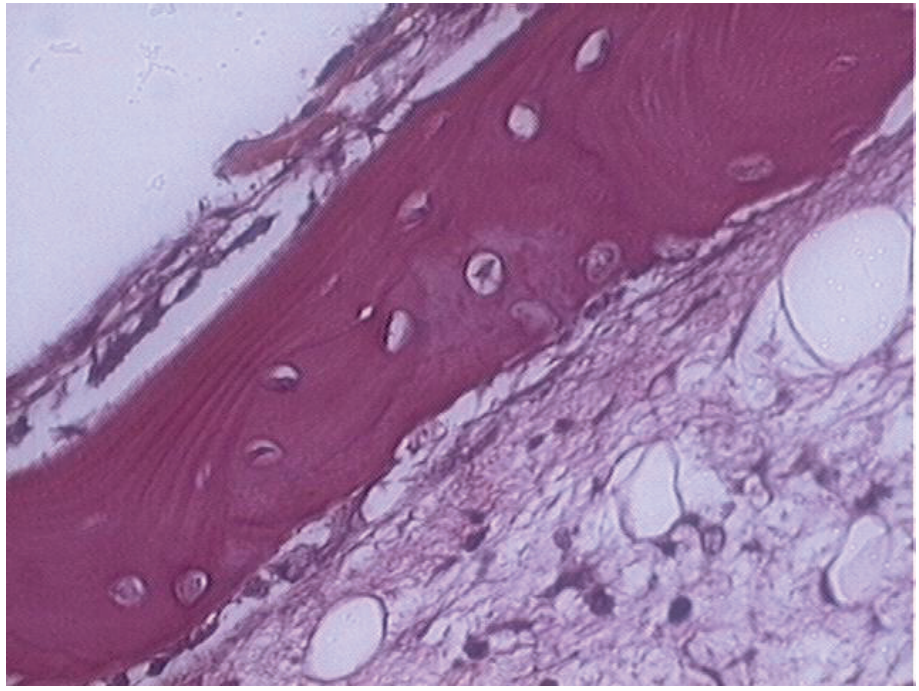

FIGURE 4 - Photomicrography showing the thickness of the new bone tissue around the screw.

Results were input into SPSS version 13.0 program $\left(\mathrm{IBM}^{\circledR}\right.$, Chicago, USA) and the ANOVA and Kruskal-Wallis tests for multiple comparisons with a significance level of $p \leq 0.001$ because many groups had constant values and did not have a normal distribution.

\section{Results}

Analyzing torque $\mathrm{X}$ time and the ICN: Control group: ICN was significantly different $(p \leq 0.001)$ from the other groups. This was due to excessive bleeding, which made it impossible to count inflammatory cells. 0 N.cm torque group: ICN was significantly different $(\mathrm{p} \leq 0.001)$ from other groups $(5 \mathrm{~N} . \mathrm{cm}$ and 10 N.cm) for the 7-day period. A smaller ICN during the acute inflammatory phase suggests a smaller surgical trauma. 5 N.cm torque group: ICN was significantly different $(\mathrm{p} \leq 0.001)$ from the control group on days $7,14,21$, and 42 after surgery. We found a larger ICN in this group on days $7,14,21$, and 42 compared to those values in the 0 N.cm and 10 N.cm groups, but this was not statistically significant. $10 \mathrm{~N} . \mathrm{cm}$ torque group: ICN was significantly different $(\mathrm{p} \leq 0.001)$ from the control group on days $7,14,21$, and 42 after surgery. We found a larger ICN in this group, without statistical significance, compared to the 0 N.cm and 5 N.cm groups on days $7,14,21$, and 42 . Although there was a tendency toward a higher ICN with increasing torque, the results had no statistical difference (Figure 5). 


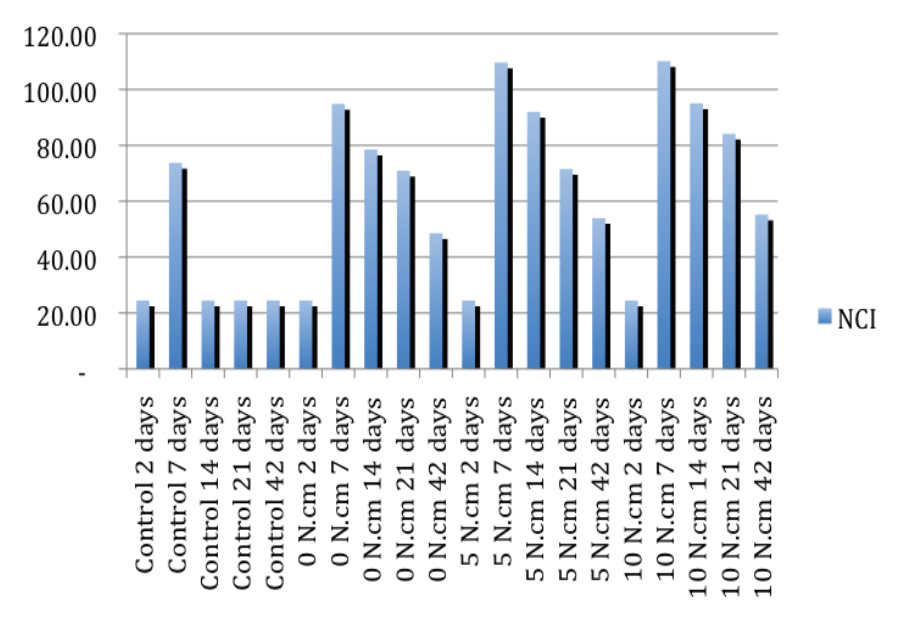

FIGURE 5 - Analyzing torque X time and ICN.

Analyzing torque $\mathrm{X}$ time and mean BTT: Control group: BTT was significantly different $(p \leq 0.001)$ from the 0 N.cm torque group on days 14,21 , and 42 , from the $5 \mathrm{~N} . \mathrm{cm}$ torque group on days 14 and 42, and from the $10 \mathrm{~N} . \mathrm{cm}$ torque group on day 42, suggesting that there is bone formation during the final period of tissue repair when screws are present. 0 N.cm group: BTT was significantly different $(\mathrm{p} \leq 0.001)$ from the control group on days 14,21 , and 42 . When analyzed for different days, the same torque value was associated with thicker bone formation on days 14,21 , and 42 than on days 2 and $7(p \leq 0.001)$. There was no statistical significance between this group and the $5 \mathrm{~N} . \mathrm{cm}$ torque group or the $10 \mathrm{~N} . \mathrm{cm}$ torque group on days 14,21 , and $42.5 \mathrm{~N} . \mathrm{cm}$ group: BTT was significantly different $(\mathrm{p} \leq 0.001)$ from the control group on days 14,21 , and 42 . When analyzed for different days, the same torque value was associated with thicker bone formation on days 14,21 , and 42 than on days 2 and $7(p \leq 0.001)$. There was no statistical significance between this group and the $0 \mathrm{~N} . \mathrm{cm}$ torque group or the $10 \mathrm{~N} . \mathrm{cm}$ torque group on days 14, 21, and 42.10 N.cm group: BTT was significantly different $(\mathrm{p} \leq 0.001)$ from the control group on days 14,21 , and 42 . When analyzed for different days, the same value was associated with thicker bone formation on days 14,21 , and 42 than on days 2 and $7(p \leq 0.001)$. There was no statistical significance between this group and the $0 \mathrm{~N} . \mathrm{cm}$ torque group or the $5 \mathrm{~N} . \mathrm{cm}$ torque group on days 14,21 , and 42 . Although there was a trend toward thicker bone formation when lower torque values were applied, the results were not significantly different (Figure 6).

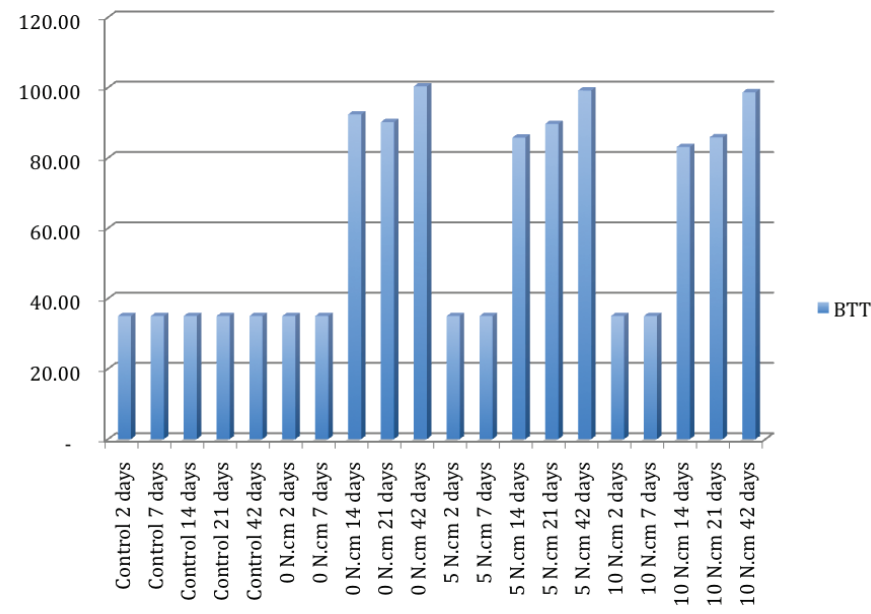

FIGURE 6 - Analyzing torque X time and the mean of BTT.

\section{Discussion}

In vitro studies have been performed to investigate the mechanical principles of implants, but their interaction with biological factors has not been studied ${ }^{5,9-12}$. In $1987^{13}$, it was established that mechanical stimuli are the primary mechanism for control of bone formation. Osteoblastic differentiation depends on the strength and the stress applied ${ }^{13}$. One of the most important criteria for treatment success is to provoke minimal trauma at the surgical site. This requires the correct technique and the correct placement of material over bone ${ }^{6,14}$. An in vitro study ${ }^{9}$ correlated the insertion torque of the implants with stability in fresh bone, and concluded that these are directly associated. The primary stability of an implant can be evaluated by a specific torquimeter? High torque values don't mean that an implant will be adequately attached to bone. In fact, torque values approaching the experimentally determined maximum allowable value can lead to microfractures around the implant. In those studies, an industrial torquimeter was used rather than a specific instrument. There are some disadvantages to an industrial torquimeter, including the size and the difficulty in sterilization. Because of this, we preferred to manufacture a prototype of such instrument.

In $1993^{3}$, one paper reported that the insertion torque could predict the stability of the mechanical system. Other authors agreed with that ${ }^{15-19}$. Other authors reported a correlation between axial force and torque ${ }^{5,15-18,20}$. In such procedures, it is suggested that screws should be placed gently ${ }^{21,22}$. One author documented a large variation in the insertion torque values applied by training surgeons and orthopedic surgeons, suggesting that professionals should periodically check their perception of torque values by using a torquimeter ${ }^{21}$. Those studies show that implant placement 
is empirical and that there is no applicable pattern that can be easily taught to surgeons in training. These studies, however, focused on mechanical factors, not biological factors. Another study reported a maximum insertion torque (without micro fractures) of 70 N.cm on bicortical a base and $50 \mathrm{~N} . \mathrm{cm}$ on a monocortical base ${ }^{10}$. The excessive torque, defined as when bone tissue was scraped off by the implant, caused a loss of $40 \%$ of tensile strength on removal ${ }^{22}$. In $2002^{23}$, it was reported that bone damage could result in bone necrosis and loss of the implants. If the discrepancy between the maximum diameter of the screw and the drill is bigger than $1 \%$, fractures can occur in adjacent tissue.

Such information demonstrates the importance of the in vitro digital torquimeter analysis in a rabbit tibia (pilot project) when a maximal insertion torque value was established and excessive forces were avoided. It was thus necessary to standardize torque values in this study because of the wide range of torque values that can be used over different kinds of bones; many factors can influence torque, such as region, screw model and others. In $2003^{24}$, it was suggested that the magnitude of force between the bone and the implant determines success. It was observed that necrosis is seen around the implant (one millimeter) after placement. This dead tissue gives support during healing and is replaced by healthy tissue later. Activity causes tension over the bone and can interfere with cellular adaptation directly or indirectly ${ }^{25}$. Implant tension can destroy adjacent bone tissue at the same time that tissue reshaping occurs according to Wolff's $\mathrm{Law}^{26}$. Microtension can also be a favorable stimulus during implant cicatrisation ${ }^{27,28}$. Our results support such studies. We also observed that the higher the torque intensity, the bigger the number of inflammatory cells.

Local tissue response is very important during the first weeks after implantation until bone fractures can be stabilized by bony callus ${ }^{29}$. We assayed bone repair at various time points, based on tissue repair period in rabbits (approximately three times faster than human metabolism). We decided to study the initial post-surgical trauma period through final bone tissue repair. Over the early days of the study ( 7 and 14 days), we observed a greater number of inflammatory cells when higher torque was applied. Excessive drill speed can cause necrosis through thermal damage, so this should be avoided ${ }^{23,27}$. The maximum temperature that can be tolerated by bone tissue without permanent damage is $47^{\circ} \mathrm{C}$ for one minute ${ }^{27}$. Higher temperatures can cause bone absorption and cell degeneration. Lower temperatures allow bone regeneration. Copious irrigation during drilling is suggested to avoid thermal damage $^{27}$. In this study, we used an electric drill with a controlled and constant speed, along with copious irrigation with $0.9 \%$ saline. We noted intense bleeding in the control sites on day 2 postsurgery. When control perforations were analyzed on days 7, 14, 21 , and 42 , the perforation site could not be localized nor could we see an inflammatory process or cell death, which suggests that we had an adequate thermal control with minimal interference to the experiment.

Studies on the mechanical tension of metallic implants over bone tissue consider micro tension over bone tissue to be a favorable stimulus to cicatrisation, causing, for instance, an improvement of bone density ${ }^{27,28}$. Results from 14, 21, and 42 days after surgery show a different amount of bone tissue $(p<0.001)$ compared to days 2 and 7 . Besides that, there was no statistically significant difference between the groups on multiple comparisons when torque intensity was analyzed. The initial torque is an important factor in the screw stability on bone tissue. However, excessive force may cause necrosis and ischemia at the screw-tissue interface ${ }^{29}$. In 2006, 124 orthodontic implants were analyzed in 41 patients $^{30}$. A small torquimeter was developed to evaluate the insertional torque and to compare treatment success ${ }^{30}$. It was observed that the group with the best results was the one with moderate insertional torque (between 5 N.cm and 10 N.cm); the other groups received less than 5 N.cm or more than 10 N.cm. The present study suggests that the higher the torque intensity, the bigger the ICN on days 7, 14, 21, and 42 after surgery, but this trend had no statistical significance. We observed that in the presence of screws, a thicker layer of bone tissue was formed after day 14 when lower torque was applied, but this result was not statistically significant. We found a thicker bone tissue layer around the screws on days 14, 21, and 42 as compared to days 2 and 7 after surgery.

\section{Conclusions}

The histological findings in this study did not achieve statistical significance. There was a trend toward an increase in inflammatory cells found in the bone tissue surrounding the titanium screws, which were the recipients of the largest torque effect. In addition, there was a tendency to form a lower thickness in the tissues surrounding the bone screws when they were inserted with higher torque. We conclude that there is a need for additional in vivo studies on the torque of insertion of titanium screws, to produce new insights.

\section{References}

1. Schmoker R, Spiessl B, Tschopp HM, Prein J, Jaques WA. Functionally stable osteosynthesis of the mandible by means of an excentric-dynamic compression plate. Results of a follow-up of 25 
cases. SSO Schweiz Monatsschr Zahnheilkd. 1976;86(2):167-85.

2. Ueda M, Matsuki M, Jacobsson M. The relationship between insertion torque and removal torque analyzed in fresh temporal bone. Int J Oral Maxillofac Implants. 1991;6(4):442-7.

3. Okuyama K, Sato K, Abe E, Inaba H, Shimada Y, Murai H. Stability of transpedicle screwing for the osteoporotic spine: An in vitro study of the mechanical stability. Spine. 1993;18(15):2240-5.

4. Hobkirk JA, Watson RM. Color Atlas and Text of Dental and Maxillo-Facial Implants. London: Mosby-Wolf; 1995.

5. Cho SA, Park KT. The removal torque of titanium screw inserted in rabbit tibia treated by dual acid etching. Biomaterials. 2003;24(20):3611-7.

6. Heitz-Mayfield LJ, Schimid B, Weigel C. Does excessive occlusal load affect osseointegration? An experimental study in the dog. Clin Oral Implants Res. 2004;15(3):259-68.

7. Tricio J. Implant stability related to insertion torque force and bone density: an in vitro study. J Prosthet Dent. 1995;74(6):608-12.

8. Ueda M, Matsuki M, Jacobsson M. The relationship between insertion torque and removal torque analyzed in fresh temporal bone. Int J Oral Maxillofac Implants. 1991;6(4):442-7.

9. Daftari TK, Horton WC, Hutton WC. Correlations between screw hole preparation, torque insertion, and pullout strength for spinal screws. J Spinal Disord. 1994;7(2):139-45.

10. Ryken TC, Clausen JD, Traynelis VC, Goel VK. Biomechanical analysis of bone mineral density, insertion technique, screw torque, and holding strength of anterior cervical plate screws. J Neurosurg. 1995;83(2):325-9.

11. Koistinen A, Santavirta S, Lappalainen R. Apparatus to test insertion and removal torque of bone screws. Proc Inst Mech Eng H. 2003;217(6):503-8.

12. Albreksson T, Zarb G, Eriksson AR. The long-term efficacy of currently used dental implant: a review and proposed criteria of success. Int J Oral Maxillofac Implants. 1986;1(1):11-25.

13. Carlson GD, Abitbol JJ, Anderson DR, Krag MH, Kostuik JP, Woo SL, Garfin SR. Screw fixation in the human scrum: An in vitro study of the biomechanics of fixation. Spine. 1992;17(6 Suppl):S196-203.

14. Daftari TK, Horton WC, Hutton WC. Correlations between screw hole preparation, torque of insertion, and pullout strength. J Spinal Disord. 1994;7(2):139-45.

15. Ryken TC, Clausen JD, Traynelic VC, Goel VK. Biomechanical analysis of bone mineral density, insertion technique, screw torque, and holding strength of anterior cervical plate screw. J Neurosurg. 1995;83(2):325-9.

16. Snyder BD, Zaltz I, Hall JE, Emans JB. Predicting the integrity of vertebral bone screw fixation in anterior spinal instrumentation. Spine. 1995;20(14):1568-74.
17. Zdeblick TA, Kunz DN, Cooke ME, MaCabe R. Pedicle screw pullout strength: correlation with insertional torque. Spine. 1993;18(12):1673-6.

18. Polly DW Jr, Orchowski JR, Ellenbogen RG. Revision pedicle screws. Bigger, longer shims--what is best? Spine. 1998;23(12):1374-9.

19. McGuire R, St John KR, Agnew SG. Analysis of the torque applied to bone screws by trauma surgeons. Comparisons based on years of experience and material of implant construction. Am J Orthop. 1995;24(3):254-6.

20. Lowson KJ, Brems J. Effect of insertion torque on bone screw pullout strength. Orthopedics. 2001;24(5):451-4.

21. Sowden D, Shmilz JP. AO self-drilling and self-tapping screws in rat calvarial bone: an ultra structural study of the implant interface. J Oral Maxillofac Surg. 2002;60(3):294-9; discussion 300.

22. Nkenke E, Lehner B, Thams U, Neugebauer J, Steveling H, Radespiel-Tröger M, Neukam FW. Bone contact, growth, and density around immediately loaded implants in the mandible of mini pigs. Clin Oral Implants Res. 2003;14(3):312-21.

23. Fritton SP, McLeod KJ, Rubin CT. Quantifying the strain history of bone: spatial uniformity and self-similarity of low-magnitude strains. J Biomech. 2000;33(3):317-25.

24. Linder L, Albrektsson T, Bränemark P-I. Hansson HA, Ivarsson B, Jönsson U, Lundström I. Electron microscopic analysis of the bonetitanium interface. Acta Orthop Scand. 1983;54(1):45-52.

25. Frost HM. The role of changes in mechanical usage set points in the pathogenesis of osteoporosis. J Bone Mineral Res. 1992;7(3):25361.

26. Matsumoto H, Ochi M, Abiko Y, Hirose Y, Kaku T, Sakaguchi K. Pulsed electromagnetic fields promote bone formation around dental implants inserted into the femur of rabbits. Clin Oral Implants Res. 2000;11(4):354-60.

27. Mallaoglu N, Çetiner S, Aspaslan C. The early tissue response to titanium and Lactosorb screws. Dent Traumatol. 2003;19(3):13944.

28. Eriksson AR, Albrektsson T. Temperature threshold levels for heatinduced bone tissue injury: A vital microscopic study in the rabbit. J Prosthet Dent. 1983;50(1):101-7.

29. Meredith N. Assessment of implant stability as a prognostic determinant. Int J Prosthodont. 1998;11(5):491-501.

30. Motoyoshi M, Hirabayashi M, Uemura M, Shimizu N. Recommended placement torque when tightening an orthodontic mini-implant. Clin Oral Implants Res. 2006;17(1):109-14.

\section{Correspondence:}

FabrícioTogni

Rua Duque de Caxias, 306

80510-200 Curitiba - PR Brasil

Tel: (55 41)3013-4424

tognibucomaxilo@hotmail.com

fabricio.togni@utp.br
Conflict of interest: none Financial source: CAPES

Received: December 10, 2010

Review: February 14, 2011

Accepted: March 15, 2011 